\title{
First record of Corbicula fluminalis (Müller, 1774) in Lake Garda (Italy), living in sympatry with Corbicula fluminea (Müller, 1774)
}

\author{
Francesca CIUTTI* and Cristina CAPPELLETTI \\ IASMA Research Centre - Fondazione Edmund Mach, Via E. Mach 1, 38010 S. Michele all'Adige (TN), Italy \\ *e-mail corresponding author: francesca.ciutti@iasma.it
}

\begin{abstract}
The first record of Corbicula fluminalis (Müller, 1774) (Mollusca: Bivalvia: Veneroidea: Corbiculidae) in Lake Garda (Italy) is presented. This clam was observed in July 2008 along the lake shore, with a high number of shells; sampling of lake sediment revealed the presence of live specimens. C. fluminea (Müller, 1774) has already been recorded in Lake Garda since 2002. The need for further studies on the presence and the spread of the two clams and the biodiversity of the invertebrate community of the lake is underlined, in relation to recent records of other invasive species, such as Dikerogammarus villosus (Sowinsky, 1894).
\end{abstract}

Key words : invasive species

\section{INTRODUCTION}

Lake Garda, the largest Italian lake (volume $=49$ $\mathrm{km}^{3}$, surface $=368 \mathrm{~km}^{2}$ and maximum depth $=350 \mathrm{~m}$ ) along with the lakes Iseo, Como, Lugano and Maggiore, is one of the deep Insubrian lakes south of the Alps. The lake is part of the ILTER network (International Long Term Ecological Research). Recent limnological investigations have shown that Lake Garda's trophic condition ranges from oligotrophy to mesotrophy (Salmaso 2005).

As observed in other countries, large lakes in particular are involved in an important process of colonization by alien species, which seldom show invasive behavior (Beeton 2002).

Among non-indigenous freshwater bivalves, the presence of Dreissena polymorpha (Pallas, 1771) was observed in Lake Garda since the 1970s and Corbicula fluminea (Müller, 1774) has been also recently recorded at the Manerba and Peschiera sampling stations (Giusti \& Oppi 1972; Bianchi et al. 1974; Annoni et al. 1978; Franchini 1978; Nardi \& Braccia 2004; Ciutti et al. 2007).

A further observation in Lake Garda of another alien bivalve, Corbicula fluminalis (Müller, 1774) (Mollusca: Bivalvia: Veneroidea: Corbiculidae) was made in July 2008.

The genus Corbicula has its native range of distribution across tropical and subtropical regions of Africa, Asia, the Malay Archipelago, the Philippines, New Guinea and Eastern Australia (Morton 1986); it has been the object of numerous studies because of the rapid expansion of its range and because of its potential danger to native aquatic communities (Korniushin 2004; Counts 2006). C. fluminea in particular is now widespread in many European countries (Austria, Belgium, Bulgaria, Czech Republic, France, Germany, Hungary,
Luxembourg, Netherlands, Portugal, Romania, Spain, Switzerland and United Kingdom) (Cianfanelli et al. 2007).

The taxonomic status of the genus Corbicula is still unresolved, as there is no agreement between investigators, neither about the general number of valid species, nor about species identity of the morphotypes recorded in America and Europe, i.e., some authors consider $C$. fluminea and C. fluminalis as morphotypes and the Global Invasive Species Database (GISD) consider them as synonymous (Korniushin 2004; Paunović et al. 2008).

Recent reviews on alien invertebrates and molluscs in Italy report for $C$. fluminalis a single record from a small alpine lake in Trentino province (Northern Italy) (Lori et al. 2005), while C. fluminea has been observed in several sites in the River Po basin since 1998 (Nardi \& Braccia 2004; Cianfanelli et al. 2007; Ciutti et al. 2007; Gherardi et al. 2008).

\section{STUDY SITES AND METHODS}

The observation of the presence of dead specimens (shells) of C. fluminalis was made in July 2008 on the south east lake's shore at Castelnuovo del Garda and Lazise (Verona Province) (Castelnuovo del Garda, locality Ronchi: $45^{\circ} 27^{\prime} 28,23^{\prime \prime} \mathrm{N} 10^{\circ} 42^{\prime} 12,59 "$ E; Lazise, locality Pacengo: $45^{\circ} 28^{\prime} 05,66^{\prime \prime} \mathrm{N} 10^{\circ} 42^{\prime} 46,10^{\prime \prime} \mathrm{E}$ ).

In the same sites $C$. fluminea was also present. Shells belonging to the two taxa were collected from shore deposits and 130 specimens for each taxon were measured for valve length, height and width using a digital caliper to the nearest $0.01 \mathrm{~mm}$. To search for living specimens, littoral samples in different sites of the two localities were taken using a handnet dragged for $2 \mathrm{~m}$, within a water depth ranging from 0.20 to 1.5 $\mathrm{m}$. 


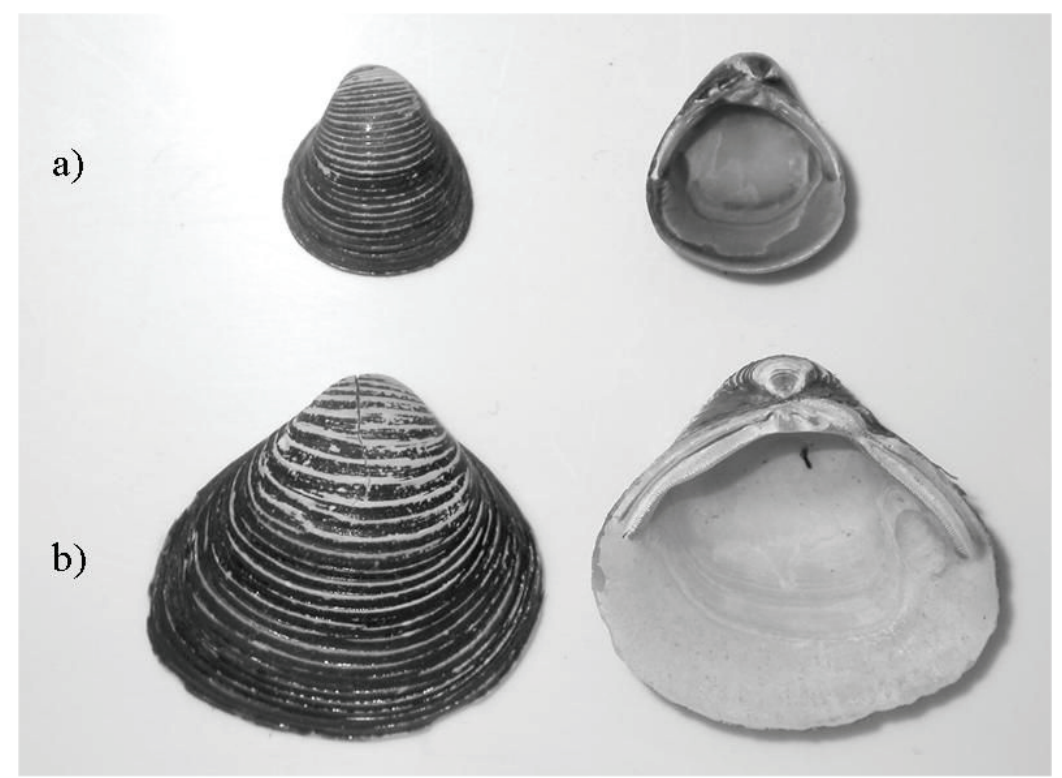

Fig. 1: Exterior and interior valve view of C. fluminalis (a) and C. fluminea (b).

Tab. 1. Length, height and width of valves of $C$. fluminalis and $C$. fluminea (mean, standard deviation and range).

\begin{tabular}{lcccccccc}
\hline & \multicolumn{3}{c}{ C. fluminalis } & & \multicolumn{3}{c}{ C. fluminea } \\
\cline { 2 - 3 } \cline { 6 - 8 } & range & mean & st. dev. & & range & mean & st. dev. \\
\hline lenght $(\mathrm{mm})$ & $4.74-13.57$ & 9.61 & 2.40 & & $4.19-24.84$ & 13.78 & 5.08 \\
height $(\mathrm{mm})$ & $4.44-15.79$ & 10.40 & 3.05 & & $3.93-24.47$ & 12.88 & 5.11 \\
width $(\mathrm{mm})$ & $1.81-7.03$ & 4.63 & 1.31 & & $1.71-8.77$ & 4.95 & 1.85 \\
\hline
\end{tabular}

\section{RESULTS}

In Castelnuovo del Garda there were two distinct shell deposits along the shore, resulting in an impressive scene: an outer larger deposit from 1 to 4 meters from the water line, with high numbers of $C$. fluminea shells, and an inner deposit in the area pounded by waves where $C$. fluminea was mixed with $C$. fluminalis.

In Lazise, $C$. fluminalis shells were dominant in the area pounded by waves, but $C$. fluminea was also present.

The two clams were clearly distinguishable from the patterns of shell sculpture, shape, and color: the $C$. fluminalis shell shows finer ridges, with a violet inner surface, while the $C$. fluminea shell shows coarser ridges with whitish inner surface (Fig. 1). The relationships between length, height and width are also characteristic (Fig. 2).

In Castelnuovo del Garda the population of $C$. fluminalis was composed of shells ranging from 4.74 to $13.57 \mathrm{~mm}$ in lenght, while $C$. fluminea varies from 4.19 to $24.84 \mathrm{~mm}$ (Tab. 1).

C. fluminea specimens had a maximum shell height of $24.47 \mathrm{~mm}$, referable to an age of 3 years, in agreement with data observed in Lake Garda (Peschiera) in 2003 and with longevity of the species as described for other environments (Mouthon \& Parghentanian 2004; Ciutti et al. 2007).

Sampling in the littoral zone of Castelnuovo del Garda revealed the presence of living specimens of $C$. fluminea and $C$. fluminalis, with maximum densities of 19 ind $\mathrm{m}^{-2}$ and 5 ind $\mathrm{m}^{-2}$ respectively. The two clams were found together, on substrata characterized by the presence of pebbles and cobbles. In Lazise however, no clams were found up to a water depth of $1.5 \mathrm{~m}$ in two littoral sites characterized by sand or pebbles. Shore samples at Peschiera, where $C$. fluminea was previously recorded in 2003, did not reveal the presence of $C$. fluminalis specimens.

\section{DISCUSSION}

There is a large consensus today that invasive alien species are one of the most important direct drivers of biodiversity loss and change in ecosystem services, together with habitat change, climate change, overexploitation of species and pollution (Millennium Ecosystem Assessment 2005).

Compared to terrestrial systems, inland waters are highly vulnerable to either inadvertent or deliberate introductions of species and to their subsequent spread, as a result of the intensive human uses, of the natural linkages among streams and lakes, and the dispersal capability of aquatic organisms (Gherardi et al. 2008). 

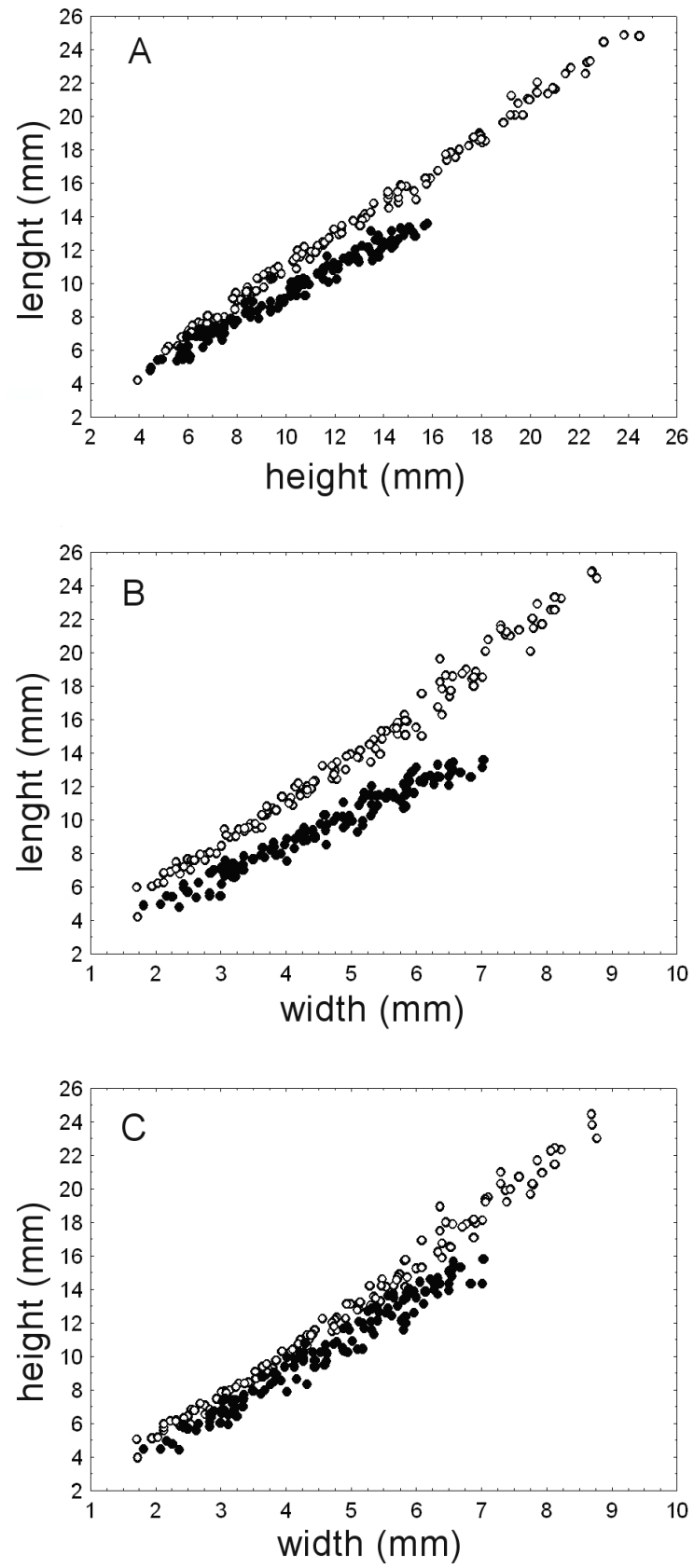

Fig. 2. Scatterplots of the relationships between length and height (A), lenght and width (B) and height and width (C) (in millimeters) in C. fluminalis (black circles) and $C$. fluminea (white circles).

In the last decades, Lake Garda has been subject to invasion of bivalves such as $D$. polymorpha, $C$. fluminea and C. fluminalis, species which are considered among the 100 worst invasive species for Europe (DAISIE). A recent record in the lake of the invasive amphipod Dikerogammarus villosus (Sowinsky, 1894) gives the idea of the vulnerability of Lake Garda to biological invasions (Casellato et al. 2006, 2007).
The two clams $C$. fluminalis and $C$. fluminea tend to show invasive behavior in Lake Garda, for rapidity in colonization and high numbers of individuals. They live in sympatry in the same kind of substrata, a phenomenon which has been already observed in other environments, mainly canals and rivers (Mouthon \& Parghentanian 2004; Paunović et al. 2007).

Gherardi et al. (2008) report that the main pathway of introduction for C. fluminea is stocking activities, while the mode of introduction for $C$. fluminalis is still unknown. This aspect should be studied for Lake Garda, where the introduction of another bivalve $D$. polymorpha has been related to shipping (Giusti \& Oppi 1972). An extensive study of the two clams in Lake Garda is advisable, in order to identify both the actual consistency of populations and short and long term trends, and to assess the relationships between introduction of invasive species, biodiversity and changes in ecosystem services.

\section{REFERENCES}

Annoni, D., I. Bianchi, A. Girod \& M. Mariani. 1978. Inserimento di Dreissena polymorpha (Pallas) (Mollusca Bivalvia) nelle Malacocenosi costiere del Lago di Garda (Nord Italia). Quad. Civ. Staz. Idrobiol. Milano, 6: 7-84.

Beeton, A.M. 2002. Large freshwater lakes: present state, trends, and future. Environmental Conservation, 1: 21-38.

Bianchi, I., A. Girod \& M. Mariani. 1974. Densità, strutture di popolazione e distribuzione di Dreissena polymorpha nel bacino idrografico del Benaco. Arch. Moll., 104: 97-105.

Casellato, S., G. La Piana, L. Latella \& S. Ruffo. 2006. Dikerogammarus villosus (Sowinsky, 1894) (Crustacea, Amphipoda, Gammaridae) for the first time in Italy. It. J. Zool., 73(1): 97-104.

Casellato, S., A. Visentin \& G. La Piana. 2007. The predatory impact of Dikerogammarus villosus, a danger for fish. In: F. Gherardi (Ed.), Biological invaders in inland waters: profiles, distribution, and threats. Invading Nature. Springer Series in Invasion Ecology, Springer, Dordrecht, The Netherlands: 495-506.

Cianfanelli, S., E. Lori \& M. Bodon. 2007. Non-indigenous freshwater molluses and their distribution in Italy. In: F. Gherardi (Ed.), Biological invaders in inland waters: profiles, distribution, and threats. Invading Nature. Springer Series in Invasion Ecology, Springer, Dordrecht, The Netherlands: 103-121.

Ciutti, F., A. Girod \& M. Mariani. 2007. Considerazioni su una popolazione di Corbicula fluminea (Müller, 1774) nel Lago di Garda sud-orientale (Italia). Natura Bresciana, 35:121-124.

Counts, C. L., III. 2006. Corbicula, an annotated bibliography. http://www.carnegiemnh.org/mollusks/corbicula.doc: 436 pp.

Franchini, D.A. 1978. Distribuzione verticale di Dreissena polymorpha nel lago di Garda. Boll. Zool Ital., 45: 257260.

Gherardi, F., S. Bertolino, M. Bodon, S. Casellato, S. Cianfanelli, M. Ferraguti, E. Lori, G. Mura, A. Nocita, N. Riccardi, G. Rossetti, E. Rota, R. Scalera, S. Zerunian, \& E. Tricarico. 2008. Animal xenodiversity in Italian inland waters: distribution, modes of arrival, and pathways. Biological Invasions, 10: 435-454.

Giusti, F. \& E. Oppi. 1972. Dreissena polymorpha (PALLAS) nuovamente in Italia. (Bivalvia, Dreissenidae). Mem. Mus. Civ. St. Nat. Verona, 20: 45-49. 
Korniushin, A.V. 2004. A revision of some Asian and African freshwater clams assigned to Corbicula fluminalis (Müller, 1774) (Mollusca: Bivalvia: Corbiculidae), with a review of anatomical characters and reproductive features based on museum collections. Hydrobiologia, 529: 251270.

Lori, E., M. Bodon, and S. Cianfanelli. 2005. Molluschi continentali alieni in Italia: presenza e distribuzione. Notiziario S.I.M. 23, 71. Available at http://www.sim-online.it/.

Millennium Ecosystem Assessment. 2005. Ecosystem and human well-being: biodiversity synthesis. World Resources Institute, Washington, DC.

Mouthon, J. \& T. Parghentanian. 2004. Comparison of the life cycle and population dynamics of two Corbicula species,
C. fluminea and C. fluminalis (Bivalvia: Corbiculidae) in two French canals. Arch. Hydrobiol., 2: 267-287.

Nardi, G. \& A. Braccia. 2004. Prima segnalazione di Corbicula fluminea (O.F. Müller, 1774) per il Lago di Garda (Provincia di Brescia) (Mollusca Bivalvia, Corbiculidae). Bollettino Malacologico, 39: 181-184.

Paunović, M., B. Csányi, S. Knežević, V. Simić, D. Nenadić, D. Jakovčev-Todorović, B. Stojanović \& P. Cakić. 2007. Distribution of Asian clams Corbicula fluminea (Müller, 1774) and C. fluminalis (Müller, 1774) in Serbia. Aquatic Invasions, 2: 99-106.

Salmaso N. 2005. Effects of climatic fluctuations and vertical mixing on the interannual trophic variability of Lake Garda, Italy. Limnol. Oceanogr., 50(2): 553-565.

Received: September 2008

Accepted: November 2008 